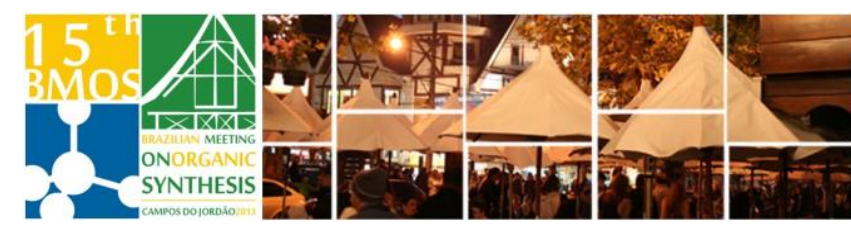

\title{
New methodology of naphthoquinones esterification with long- chain fat acids
}

\author{
Gilles, V.; ${ }^{1}$ Vieira, A. M. ${ }^{1}$ Lacerda Jr. V.; $^{1}$ de Castro, E. V. R. ${ }^{2}$ and Greco, S. J. ${ }^{*}$ \\ ${ }^{1}$ LSO\&M - Laboratório de Síntese Orgânica e Medicinal. Universidade Federal do Espírito Santo. Vitória, Brazil. \\ ${ }^{2}$ NCQP - Núcleo de Competências em Química de Petróleo. Universidade Federal do Espírito Santo. Vitória, Brazil. \\ *e-mail: sandro.greco@ufes.br
}

Keywords: juglone, Steglich Esterification, fatty acids

\section{INTRODUCTION}

Among the eldest reactions known, esterification is the simplest method to obtain esters of carboxilic acids. Since the first methodology developed by Fischer in 1895, a considerable number of new procedures have been developed like the use of anhydrides ${ }^{1}$, acyl chlorides ${ }^{2}$, Lewis Acids ${ }^{3}$ and condensation agents ${ }^{4}$.

However, the only report of juglone esterification comes from Maruo et al where they used acyl chlorides in pyridine as shown in Scheme 1.<smiles>O=C1C=CC(=O)c2c(O)cccc21</smiles>

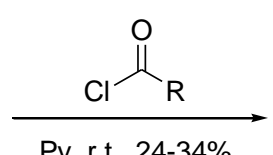

Py, r.t., 24-34\%<smiles>[R]C(=O)Oc1cccc2c1C(=O)C=CC2=O</smiles>

Scheme 1. Synthesis of long-chain esters of juglone.

In this work, we describe our studies about a new methodology to prepare naphthoquinone esters of long-chain acids.

\section{RESULTS AND DISCUSSION}

Palmitic acid was chosen as model to esterification reaction with juglone. We first investigated Fischer classical method using PTSA, ultrasound and dissecant (Scheme 2, Condition a) with no success.

$$
\begin{aligned}
& \text { a) } \mathrm{PTSA}, \mathrm{THF}, 2 \mathrm{~h} \text {, ultrasound; } \\
& \text { b) } \mathrm{H}_{3} \mathrm{BO}, \mathrm{H}_{2} \mathrm{SO}_{4} \text {, toluene, reflux, } 24 \mathrm{~h} \text {; } \\
& \text { c) } \mathrm{TSCl}, \mathrm{Py}, \mathrm{O}^{\circ} \mathrm{C} \text {; } \\
& \text { d) } \mathrm{CDI}, \mathrm{DMAP}, \mathrm{THF} \text {, r.t.; } \\
& \text { e) } \mathrm{DCC}, \mathrm{DMAP}, \mathrm{CeCl}_{3} .7 \mathrm{H}_{2} \mathrm{O} \text { THF, r.t. }
\end{aligned}
$$

Scheme 2. General methodology study of esterification of juglone with palmitic acid.

On our second attempt, acid catalysis using boric acid was applied (Scheme 2, Condition b). The crude product contained many subproducts making it impossible to purify. This unsuccessful attempt might be related to juglone instability under high temperature, leading to severe degradation ${ }^{2}$.

The use of $\mathrm{TsCl}$ as activating agent failed as well (Scheme 2, Condition c). Then, we started new attempts with condensation agents, where CDI was the first choice (Scheme 2, Condition d). This method proved unsuccessful probably by the release of imidazole, which basicity may degrade the substrate ${ }^{2}$. We then change to DCC that does not generate basic residue (Scheme 2, Condition e). $\mathrm{CeCl}_{3}$ was also add to increase the electrophilicity of the anhydride generate in situ enabling ester synthesis.

Table 1 shows the reactional time and yield.

Table 1. Results concerning esterification of juglone with DCC.

\begin{tabular}{ccc}
\hline Acid & Reaction Time $(\mathrm{h})$ & Yield $(\%)$ \\
\hline Lauric & 24 & 7 \\
Palmitic & 72 & 18 \\
Stearic & 72 & 7,5 \\
\hline
\end{tabular}

Yields are close to other described in literature ${ }^{2}$ with avoidance of inert atmosphere, anhydrous solvent and dangerous reactants.

\section{CONCLUSION}

In conclusion, we present a new attempt of esterification of naphthoquinones with success for three fatty acids using a less dangerous and easier methodology.

\section{ACKNOWLEDGEMENTS}

The authors thanks to FAPES, CAPES and CNPq for financial support and PPGQUI-UFES and NCQP.

\section{REFERENCES}

${ }^{1}$ Kankanala, K.; Reddy, V. R.; Mukkanti, K.; Pal, S. Journal of

Fluorine Chemistry, 130, 505-508, 2009

${ }^{2}$ Maruo, S.; Kuriyama, I.; Kuramochi, K.; Tsubaki, K.; Yoshida,

H.; Mizishina, Y., Bioinorganic \& Medicinal CHemistry, 2011, 19, 5803- 5012.

${ }^{3}$ Torregiani, E.; Seu, G.; Missani, A.; Appendino, G. Tetrahedron Letters, 2005, 46, 2193-2196.

${ }^{4}$ Zhu, L.; Zhu, Y.; Meng, X.; Hao, J.; Li, Q.; Wei, L.; Lin, Y..

Chem. Eur. J., 2008, 14, 10923 - 10927.

${ }^{5}$ Martínez, M. J.; Benito, P. B. Studies in Natural Products

Chemistry, 2005, 30, 303-366.

$15^{\text {th }}$ Brazilian Meeting on Organic Synthesis - $15^{\text {th }}$ BMOS - November 10-13, 2013 - Campos do Jordão, Brazil 